\title{
PENGGUNAAN TELESKOP: KESAN TERHADAP HUKUM ITHBAT KENAMPAKAN ANAK BULAN DI MALAYSIA
}

\section{The Use of A Telescope During Observation of the Lunar Crescent from the Fiqh Perspective \& Astronomical Consoderations}

\author{
Nurul Kausar Nizam* \\ Mohd Saiful Anwar Mohd Nawawi ** \\ Mohammaddin Abdul Niri** \\ Saadan Man*** \\ Mohd Zambri Zainuddin ****
}

\begin{abstract}
Observation of the lunar crescent is quite challenging, as it is influenced by various dynamic factors, particularly local and atmospheric conditions. The adoption of astronomical methods and instrumentation, such as the telescope and imaging technique using a digital single lens reflex camera (DSLR), undeniably provide better results than unaided observation. However, the results from aided observation are debated by some Muslim jurists, and, therefore, this paper attempts to analyse
\end{abstract}

* Pelajar Sarjana, Jabatan Fiqh \& Uusl, Akademi Pengajian Islam, Universiti Malaya, nurulkausarnizam@gmail.com

** Calon Doktor Falsafah, Jabatan Fiqh \& Uusl, Akademi Pengajian Islam, Universiti Malaya, Kuala Lumpur, aayatulrahman@gmail. com,maddinan@gmail.com.

*** Pensyarah Kanan, Jabatan Fiqh \& Usul, Akademi Pengajian Islam, Universiti Malaya, Kuala Lumpur, saadan@um.edu.my

**** Professor, Makmal Fizik Angkasa, Jabatan Fizik, Fakulti Sains, Universiti Malaya, Kuala Lumpur, mohdzz5@gmail.com 
the adoption and its results from the fiqh perspective and astronomical considerations. Astronomical data were taken at Teluk Kemang Negeri Sembilan, Malaysia. This study found that the adoption has its own figh justification and is still consistent with the criteria of Imkān al-Ru'yah.

Keywords: Lunar, Telescope, Observation, Criteria of Imkān AlRu'yah

\section{PENDAHULUAN}

Cerapan anak bulan merupakan asas penentuan permulaan bulan yang baru dalam kalendar Hijrah. Justeru, aktiviti cerapan anak bulan menjadi kemestian kepada ahli astronomi bagi mendapatkan data-data berkaitan untuk tujuan penentuan awal bulan. Data anak bulan akan sukar diperolehi jika dicerap dengan menggunakan mata kasar. Ini disebabkan oleh pelbagai faktor perlu diambil kira untuk anak bulan kelihatan seperti astronomi, meteorologi dan psikologi. ${ }^{1}$ Oleh yang demikian, pencerap akan menggunakan instrumen astronomi seperti teleskop yang dilengkapi peralatan perakam seperti kamera dan video supaya ia dapat membantu para pencerap melihat anak bulan yang mempunyai cahaya yang sangat minimum. ${ }^{2}$

Walau bagaimanapun berikutan daripada penggunaan teleskop, timbul situasi permasalahan berkaitan dengan penyaksian anak bulan yang tidak dapat dilihat secara fizikal menggunakan mata kasar tetapi dapat dikesan menggunakan kamera DSLR yang ditekapkan kepada teleskop melalui komputer riba. Senario ini lebih rumit sekiranya ia berlaku pada hari cerapan untuk menentukan awal Ramadan, Syawal dan Zulhijjah. Ini disebabkan

1 Kordi, Ayman S., "The Psychological Effect on Sightings of the New Moon", The Observatory 123 (2003): 219-222. Schaefer, Bradley E., "Visibility of the Lunar Crescent", Quarterly Journal of the Royal Astronomical Society 29 (1988): 511.

2 Joko Satria A, Chin Wei Loon, Nazhatulshima Ahmad et al., "Pensabitan Hilal Menerusi Teknik Pengimejan", dlm Dimensi Penyelidikan Astronomi Islam, (ed.) Saadan Man et al. (Kuala Lumpur: Jabatan Fiqh dan Usul, Akademi Pengajian Islam, Universiti Malaya, 2013), 95. 
oleh penyaksian kenampakan anak bulan pada hari berkenaan akan memberikan kesan terhadap tarikh 1 Ramadan, 1 Syawal dan 10 Zulhijjah. Berdasarkan kepada senario tersebut, artikel ini akan meneliti bagaimana penggunaan instrumen boleh diterapkan sebagai alat bantuan penglihatan mata dari perspektif astronomi serta implikasinya kepada hukum pensabitan kewujudan anak bulan dalam konteks Malaysia.

\section{PENTAFSIRAN ANAK BULAN}

Perkataan anak bulan adalah berasal daripada perkataan bahasa arab iaitu perkataan hilal yang merupakan perkataan tunggal kepada perkataan jamak ahillah. ${ }^{3}$ Perkataan ini telah disebutkan oleh Allah SWT di dalam al-Quran melalui surah al-Baqarah:

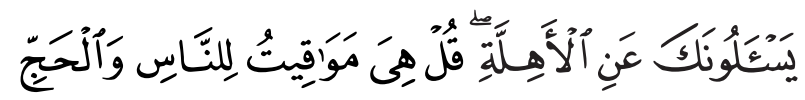

Maksudnya: Mereka bertanya kepadamu tentang bulan sabit. Katakanlah: "Bulan sabit itu adalah tanda-tanda waktu bagi manusia dan (bagi ibadat) haji.

Surah al-Baqarah (2): 189

Mengikut Ibn 'Abbās, ayat tersebut ditujukan kepada dua orang penduduk Ansar iaitu Mu'āz bin Jabal dan Tha'labah bin Ghanamah. Mereka bertanya kepada Rasulullah SAW mengenai kemunculan anak bulan yang terbit dalam keadaan tipis kelihatan seperti benang. Kemudian keadaan fizikal anak bulan beransuransur menjadi besar. Seterusnya kelihatan berbentuk bulat sepenuhnya dan ia beransur-ansur berkurang kembali menipis seperti keadaan pada peringkat awal. Lantaran itu, maka Allah SWT menurunkan ayat ini bagi menjelaskan tentang waktu bagi perlaksanaan ibadah puasa, haji dan iddah bagi para wanita. ${ }^{4}$

3 Ibrāhīm Anīs, 'Abd al-Halīm Muntașir, 'Ațiyyah al-Sawālihi et al., al-Mu jam al-Wasit (Istanbul: t. t), 2 : 992.

4 Abū al-Hasan 'Alì bin Aḥmad, al-Wajīz fì Tafsīr al-Kitāb al-'Azīz (Damsyiq: Dar al-Qalam, 1995), 1 : 153. 
Fizikal anak bulan kelihatan sebagai goresan garis cahaya yang nipis. Dalam mendefinisikan tempoh masa yang dikatakan anak bulan, terdapat beberapa pentafsiran ulama mengenai anak bulan. Al-Fayrūz Ābādī menjelaskan bahawa anak bulan merupakan fasa-fasa bulan yang kelihatan pada malam pertama sehingga malam ke-7. Tambahan pula, beliau berpendapat malam ke-26 dan 27 masih dikira sebagai anak bulan. ${ }^{5}$ Mengikut Ibn Manzūr pula, anak bulan adalah cahaya dari cakera yang dapat dilihat sewaktu malam pertama anak bulan kelihatan fasa yang berikutnya. ${ }^{6}$ Walau bagaimanapun, terdapat juga pandangan yang mentakrifkan anak bulan adalah cahaya pertama yang dilihat pada bulan sehingga malam ketiga sahaja. Selepas itu dianggap sebagai qamar. ${ }^{7}$ Oleh yang demikian, berdasarkan kepada pelbagai pendapat mengenai tempoh yang dikatakan sebagai anak bulan, maka dapat disimpulkan bahawa anak bulan adalah cahaya bulan yang dilihat oleh pencerap di kaki langit pada awal bulan dan akhir bulan Hijrah. ${ }^{8}$

Dari perspektif astronomi pula, ahli astronomi telah mengambil kira kriteria-kriteria tertentu untuk anak bulan kelihatan anak bulan pertama boleh dianggap kelihatan. Kriteria-kriteria ini lahir daripada dua pendekatan sama ada pendekatan empirikal atau teoritikal. Secara empirikal, ia berdasarkan rekod cerapancerapan anak bulan dalam tempoh tertentu. Ahli astronomi menganalisis dan membentuk kriteria kenampakan anak bulan

5 Majd al-Dīn Muhammad Ibn Ya'qūb al-Fayrūz Ābādī, Qāmūs alMuhịt (Bayrut: Maktab Taḥqīq fī Mu'assasah al-Risālah, c. 6, 1998), 1072.

6 Muḥammad Ibn Makram Ibn Manz̦ūr, Lisān al- 'Arab (Bayrūt: Dār Ihyyā' al-Turāth al-Arābī, c. 3, t. th), $15: 121$.

7 Muhammad Ahmad al-Aẓharī Abū Manșūr, Tahdhīb al-Lughah (Bayrūt: Dār Iḥyā’ al-Turāth al-'Arab̄ị, 2001), 5 : 239.

8 'Abd al-Amīr Mu'min, Qāmūs Dār 'Tlm al-Falakī (Bayrūt: Dār al'Ilm li al-Malāyīn, 2006 ), 533. 
tertentu. ${ }^{9}$ Manakala pendekatan teoritikal pula, kajian dijalankan dengan mempertimbangkan pelbagai faktor yang mempengaruhi kenampakan anak bulan. Seterusnya, model-model metematik yang deskriptif akan dibentuk. ${ }^{10}$ Kriteria teoritikal yang dihasilkan mengambil kira beberapa pembolehubah seperti jarak bulan dan matahari, kelebaran anak bulan, keamatan cahaya anak bulan, kecerahan langit, kesan bayang gunung-gunung di bulan dan peranan mata manusia dalam cerapan anak bulan. ${ }^{11}$

Justeru, Malaysia telah menerima pakai pendekatan berdasarkan kaedah empirikal yang telah diputuskan dalam Pertemuan Tahunan Tidak Rasmi Menteri-menteri Agama Negara Brunei Darussalam, Republik Indonesia, Malaysia dan Republik Singapura (MABIMS) untuk diaplikasikan pada 1 Jun $1992 .{ }^{12}$ Kriteria yang dipersetujui tersebut berdasarkan kepada syarat anak bulan dianggap kelihatan apabila kiraan memenuhi salah satu daripada syarat berikut:

$9 \quad$ Pendekatan empirikal yang digunakan oleh ahli-ahli astronomi dalam mengkaji kenampakan anak bulan. Antaranya Khadijah Ismail,"The Philosophical and Empirical Investigation on Moon Width and Brightness and Its Relationship with Crescent Visibility and Prediction Criteria in Islamic Calendar," (Disertasi Sarjana, Universiti Malaya, 2010). Fotheringham, John Knight, "On the Smallest Visible Phase of the Moon", Monthly Notices of the Royal Astronomical Society 70 (1910): 527-531. Schaefer, Bradley E., "Visibility of the Lunar Crescent", Quarterly Journal of the Royal Astronomical Society 29 (1988): 511-523.

10 Fatoohi, Louay J., Stephenson et al., "The Babylonian First Visibility of the Lunar Crescent: Data and Criterion", Journal for the History of Astronomy 30 (1999): 51-72.

11 Pendekatan teoretikal yang digunakan oleh ahli-ahli astronomi dalam mengkaji kenampakan anak bulan. Antaranya Mikhail, J.S., Asaad, A.S., Nawar, S. et al., "Improving the Crescent Visibility Limits Due to Factors Causing Decrease in the Sky Twilight Brightness", Earth, Moon and Planets, 70 (1995): 109-121. Sultan, Abdul Haq, "First Visibility of the Lunar Crescent: Beyond Danjon's Limit", The Observatory 127 (2007): 53-59. Mc Nally, D., "The Length of the Lunar Crescent", Quarterly Journal of the Royal Astronomical Society 24 (1983): 417-429.

12 Samad Abu et al., Kaedah Penentuan Awal Hijrah (Putrajaya: Jabatan Kemajuan Islam Malaysia, 2001), 10. 
a. Ketika matahari terbenam

1. Ketinggian bulan tidak kurang daripada $2^{\circ}$; dan

2. Jarak lengkung bulan-matahari tidak kurang daripada $3^{\circ}$.

ATAU,

b. Ketika bulan terbenam

1. Umur bulan tidak kurang daripada 8 jam. ${ }^{13}$

Lantaran itu, penyelidik menyimpulkan bahawa anak bulan adalah merujuk kepada fasa cahaya yang pertama kelihatan atau tidak yang berbentuk bulan sabit terbit di kaki ufuk setelah terbenamnya matahari dan selepas berlakunya ijtimak ${ }^{14}$ berdasarkan kriteria tertentu. Dalam konteks pencerapan anak bulan di Malaysia, anak bulan yang dilihat perlulah memenuhi kriteria Imkān al-Ru'yah. ${ }^{15}$

\section{SEJARAH CERAPAN ANAK BULAN DI MALAYSIA}

Realitinya di Malaysia cerapan anak bulan mula dilakukan hanya dengan melihat menerusi mata kasar dan bantuan peralatan tradisi sahaja. Usaha melihat anak bulan telah dilakukan secara rasmi sejak tahun 1934 oleh Syed Alwi bin Tahir al-Haddad di Menara Masjid Sultan Abu Bakar, Johor Bahru. ${ }^{16}$ Peralatan tradisi yang digunakan pada ketika itu ialah gawang anak bulan. ${ }^{17}$ Akan tetapi, kini di Malaysia gawang tidak lagi digunakan ketika cerapan anak bulan dilakukan.

13 Ibid.

14 Ijtimak merujuk kepada kedudukan bulan, bumi dan matahari berada pada longitud yang sama.

15 Samad Abu et.al., Kaedah Penentuan Awal Bulan Hijrah, 8.

16 Ibid.

17 Bahagian Hal Ehwal Islam, "Pelaksanaan Rukyah dan Hisab di Malaysia," (Koleksi Kertas Kerja Seminar Persatuan Falak Syar'i Malaysia, Kuala Lumpur: Persatuan Falak Syari'i Malaysia, 1993), 175. 
Setelah itu, Jabatan Ukur dan Pemetaan Malaysia (JUPEM) pula terlibat dalam usaha-usaha mencerap serta teodolit telah mula digunakan sejak tahun $1972 . .^{18}$ Kemudian, sekitar tahun 1979, teleskop telah mula digunakan. ${ }^{19}$ Pada tahun yang sama, Jawatankuasa Rukyah yang terdiri daripada 7 orang yang telah dilantik oleh Fakulti Pengajian Islam, Universiti Kebangsaan Malaysia dan diketuai oleh Haron Din bagi menjalankan kajian secara terperinci tentang faktor-faktor kesukaran anak bulan dilihat sejak tahun 1970-an. ${ }^{20}$

Perkembangan penggunaan peralatan astronomi bergerak seiring dengan perubahan pengunaan instrumen astronomi dunia. Kini khususnya di Baitul Anak bulan Teluk Kemang, aktiviti cerapan anak bulan dilakukan menggunakan teleskop yang terdiri daripada teleskop utama dan skunder, kamera DSLR (Digital Single Lens Reflect), perisian astronomi (perisian MoonC). ${ }^{21}$

\section{METODOLOGI CERAPAN ANAK BULAN}

Terdapat beberapa langkah persediaan yang perlu dilakukan sebelum pengimejan bagi mendapatkan imej anak bulan. Langkah asas yang perlu dilakukan terlebih dahulu ialah pemilihan lokasi cerapan. Lokasi yang dipilih perlulah strategik dan sesuai bagi proses pencerapan yang dilakukan. Bagi melaksanakan kajian ini, lokasi yang dipilih adalah Baitul Hilal Teluk Kemang. Lokasi ini berada pada kedudukan longitude $101^{\circ} 27^{\prime} 44^{\prime \prime}$ dan latitud 2 $27^{\circ} 44^{\prime \prime}$ serta berada pada ketinggian \pm 20 meter dari aras laut. Ketinggian

18 Mohd Zambri Zainuddin, Mohd Saiful Anwar Nawawi, Nazhatul Shima, "Sky Illumination for Lunar Crescent Visibility at Telok Kemang, Malaysia," (Proceedings of The Second Emirates Astronomical Conference at Abu Dhabi, United Arab Emirates, 30 May-1 June 2010), 45.

19 Haron Din, "Melihat Anak Bulan Di Malaysia: Masalah dan Kemungkinan" (Kertas Kerja Seminar dibentangkan di Universiti Kebangsaan Malaysia, 22-24 Januari 1982).

20 Ibid.

21 Joko Satria, Chin Wei Loon, Nazhatulshima Ahmad, et al., "Pensabitan Anak bulan Menerusi Teknik Pengimejan," Kertas Kerja Jabatan Kemajuan Islam Malaysia (Kuala Lumpur: Makmal Fizik Angkasa, Universiti Malaya, 2011), 5-8. 
pada paras ini memberikan gambaran keadaan langit yang kurang jerebu dan lebih gelap. ${ }^{22}$

Sebelum memulakan penggunaan instrumen cerapan, proses kalibrasi masa perlu dilakukan terlebih dahulu. Masa yang terdapat pada instrumen yang digunakan ketika cerapan perlu diselaraskan mengikut masa rujukan SIRIM. ${ }^{23}$ Penggunaan masa yang tepat sangat penting kerana para pencerap dapat mengetahui saat waktu kenampakan anak bulan yang pertama. Seterusnya, bermulalah pelarasan bagi instrumen seperti teleskop, kamera DSLR dan komputer riba. Terlebih dahulu pencerap perlu sentiasa dalam keadaan waspada dan sangat teliti ketika pencerapan dilakukan. Ini kerana kenampakan anak bulan biasanya amat singkat. Oleh itu, pencerap memerlukan persekitaran yang sangat kondusif bagi membantu penumpuan bagi mendapatkan imej anak bulan.

Teleskop yang digunakan bagi cerapan anak bulan adalah Teleskop Meade LX200 10". Teleskop ini menggunakan cermin bagi membentuk imej. Terdapat dua cermin yang digunakan iaitu cermin utama (cermin objektif) dan cermin skunder. Cermin yang digunakan bagi teleskop ini adalah cermin cekung yang berbentuk sfera atau parabola. Apabila teleskop dihalakan ke arah anak bulan, cahaya daripada objek tersebut akan terus tertumpu kepada cermin primer. Cermin utama merupakan elemen yang terpenting bagi teleskop ini kerana ia akan menghasilkan imej pada titik fokus. Jarak cermin di antara bidang fokus dikenali sebagai panjang fokus (focal length). Cermin cekung ini kelihatan berbentuk sfera dan hiperbola menyebabkan cahaya dapat ditumpukan secara pantulan kepada cermin skunder. Cahaya ini sterusnya dipintas oleh cermin sekunder. Kemudian imej diperbesarkan lagi dan akhirnya dapat dilihat menerusi kanta. ${ }^{24}$

22 Jabatan Kemajuan Islam Malaysia (JAKIM), http://www.islam.gov. my/e-falak/tempat-cerapan, diakses pada 20 Mac 2014.

23 The Malaysia Standard Time (SIRIM), http://time.sirim.my/, diakses pada 20 Mac 2014.

24 Meade Instruments, http://www.meade.com/lx200, diakses pada 20 Mac 2014. 


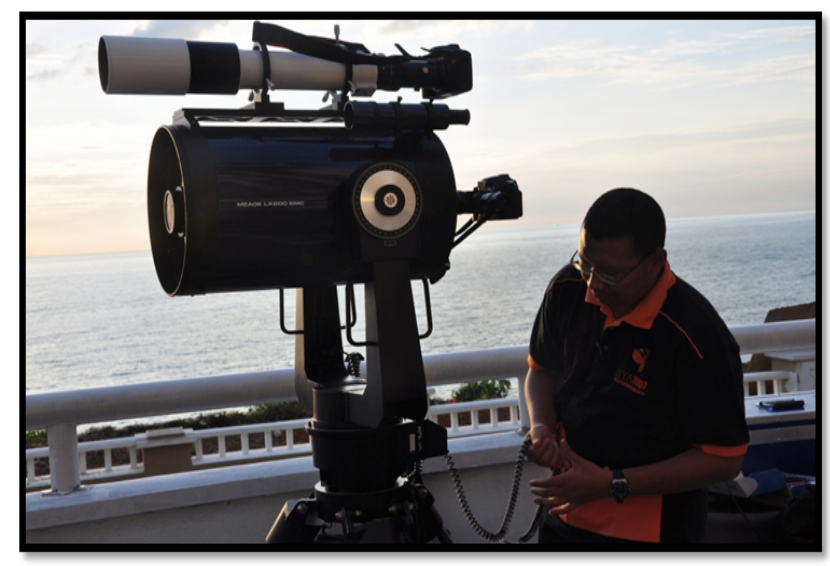

Rajah 1: Kaedah Pemasangan Kamera DSLR pada Teleskop

Kemudian, kamera DSLR dipasang pada teleskop seperti dalam rajah $1 \mathrm{di}$ atas. Pemasangan kamera DSLR ini memerlukan bantuan beberapa aksesori tambahan iaitu adapter. Tanpa adapter pengimejan bagi mendapatkan imej anak bulan tidak dapat dilaksanakan. Terdapat 3 adapter yang digunakan bagi mengukuhkan tiub teleskop dan kamera iaitu flip mirror, $t$-ring dan $t$-adapter. ${ }^{25}$ Setelah itu, pencerap perlu menyelaraskan shutter speed yang bersesuaian. Sekiranya pencerap tidak berpuas hati dengan imej yang dirakam, maka beberapa pelarasan seperti pembetulan fokus, pelarasan shuter speed yang sesuai mengikut latar belakang langit mahupun pembetulan kedudukan anak bulan sehingga berada di medan pandangan kamera perlu dilakukan. Justeru, pelbagai usaha perlu dilakukan dalam memastikan anak bulan kelihatan semasa cerapan dilakukan. Sekiranya imej anak bulan berjaya dilihat menerusi teleskop dan kamera DSLR maka anak bulan akan turut kelihatan pada skrin komputer riba. Para pencerap perlulah mengfokuskan imej anak bulan pada skrin komputer riba bagi mendapatkan paparan yang lebih jelas seperti dalam rajah 2.

25 Ibid. 


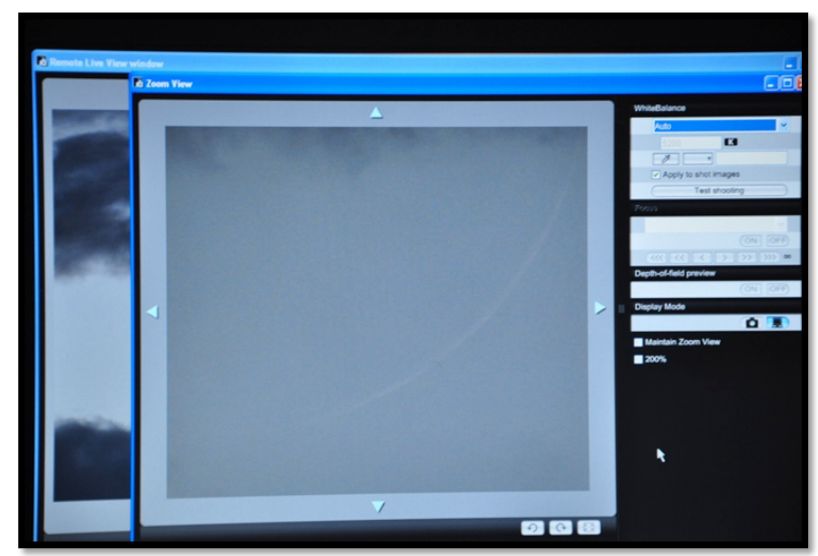

Rajah 2: Paparan Imej Anak Bulan Setelah Difokuskan pada Skrin Komputer Riba

Kriteria teoritikal yang dihasilkan mengambil kira beberapa pembolehubah seperti jarak bulan dan matahari, kelebaran anak bulan, keamatan cahaya anak bulan, kecerahan langit, kesan bayang gunung-gunung di bulan dan peranan mata manusia dalam cerapan anak bulan.

\section{IMPLIKASI PENSABITAN KEWUJUDAN ANAK BULAN}

Rentetan daripada penggunaan instrumen ini, situasi permasalahan yang timbul berikutan penggunaan teknik pengimejan adalah anak bulan tidak dapat dilihat secara fizikal oleh mata kasar, namun ia dapat dikesan menggunakan teleskop dan kamera DSLR melalui komputer riba.

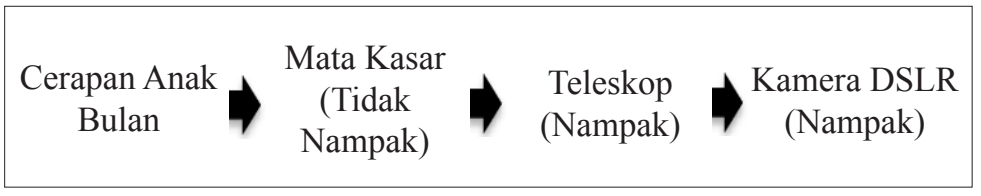

Rajah 3: Kronologi Kenampakan Anak Bulan 
Rajah 3 menunjukkan situasi permasalahan penyaksian anak bulan. Anak bulan berjaya dilihat menerusi teleskop dan kamera DSLR terlebih dahulu berbanding secara terus menggunakan mata kasar. Situasi ini berlaku ketika cerapan anak bulan Sya'ban 1231H iaitu pada 12 Julai 2010.

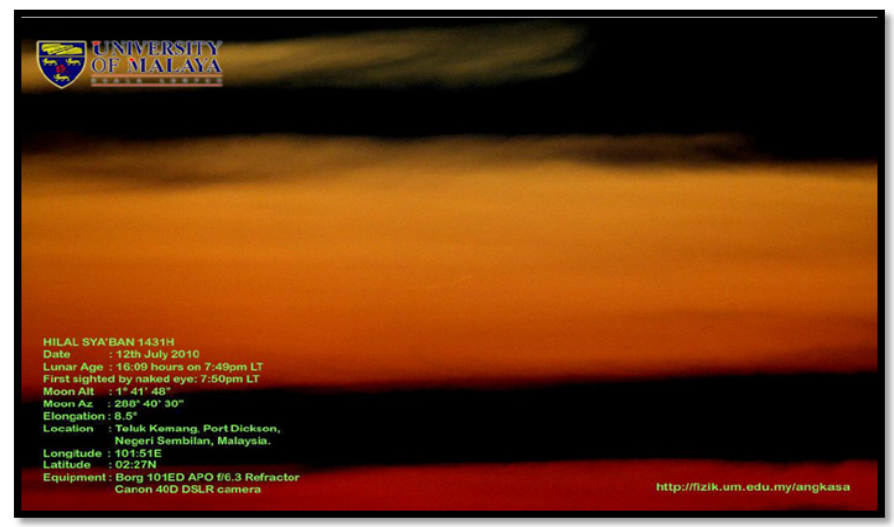

Rajah 4: Rekod Kenampakan Anak Bulan Sya'ban ${ }^{26}$

Berdasarkan rajah 4 di atas, cerapan ini dilakukan di Baitul Hilal Teluk Kemang pada kedudukan longitud $101^{\circ} 27^{\prime} 44^{\prime \prime}$ dan latitud $2^{\circ} 27^{\prime} 44^{\prime \prime}$ serta berada pada ketinggian \pm 20 meter dari aras laut. ${ }^{27}$ Instrumen yang digunakan adalah teleskop dan kamera DSLR. Cerapan ini berjaya memberikan imej anak bulan positif. Terlebih dahulu anak bulan berjaya dilihat menerusi teleskop dan kamera DSLR pada jam $7.49 \mathrm{pm}$. Altitud bulan pada ketika itu adalah $1^{\circ} 41^{\prime} 48^{\prime \prime}$. Manakala elognasi anak bulan adalah $8.5^{\circ}$. Oleh itu, timbul permasalahan dalam mengenal pasti sama ada penyaksian anak bulan menerusi teleskop dan kamera DSLR ini boleh dianggap sah sebagai anak bulan menurut justifikasi astronomi dan hukum.

26 Jabatan Fizik Angkasa, Laporan Kajian Cerapan Kenampakan Hilal Tahun 1421-1431 Hijrah (Kuala Lumpur: Makmal Fizik Angkasa), 34.

27 Jabatan Kemajuan Islam Malaysia (JAKIM), http://www.islam.gov. my/e-falak/tempat-cerapan, diakses pada 20 Mac 2014. 


\section{ANALISIS HUKUM TERHADAP IMPLIKASI KENAMPAKAN ANAK BULAN}

Dalam persoalan penentuan penyaksian anak bulan, para ulama berpandukan kepada penafsiran 3 hadis utama; ${ }^{28}$

Pertama, hadis yang diriwayatkan oleh Abū Hurayrah. Rasulullah SAW bersabda:

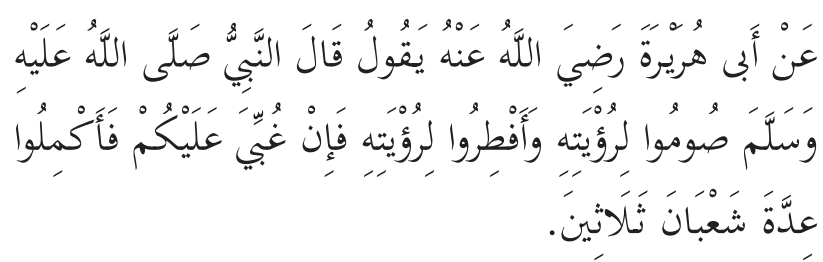

Maksudnya: "Berpuasalah kamu apabila melihat anak bulan dan berbukalah (berhari raya) sekiranya melihat anak bulan. Sekiranya mendung, maka sempurnakanlah 30 hari Syaaban." 29

Kedua, hadis yang diriwayatkan juga oleh Ibn 'Umar, Rasulullah SAW bersabda:

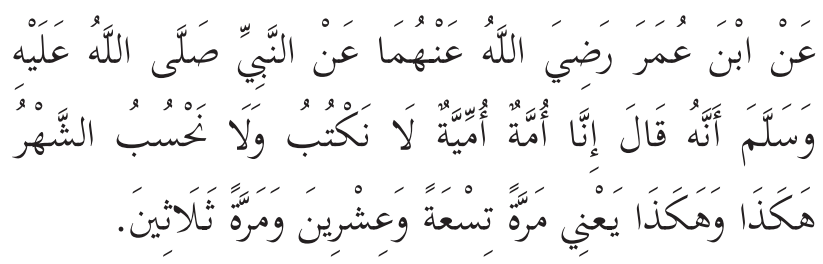

Maksudnya: "Sesungguhnya umat yang buta huruf, tidak tahu menulis dan tahu mengira, bulan adalah

28 Yūsuf al-Qaraḍ̄āī, Fiqh al-Ṣiyām (Qāhirah: Maktabah al-Wahbah, 2006), 22.

29 Muhammad Ibn Ismā'il Abū 'Abd Allah al-Bukhārī, Șah̄ịh alBukhārī, Kitāb al-Șaum, dalam Bab Qawl al-Nabī SAW, "Idhā Ra'aytum al-Hilāl Fașūmū wa Idhā Ra'aytumūhu Faafțirū”, hadis no. 1909 (Qāhirah: al-Maṭba'ah al-Salafiyyah, 1403H), 3 : 26-27. 
sekian sekian. Iaitu sesekali 29 hari dan sesekali lagi 30 hari." ${ }^{\prime 30}$

Ketiga, hadis yang diriwayatkan oleh Ibn 'Umar, Rasulullah SAW bersabda:

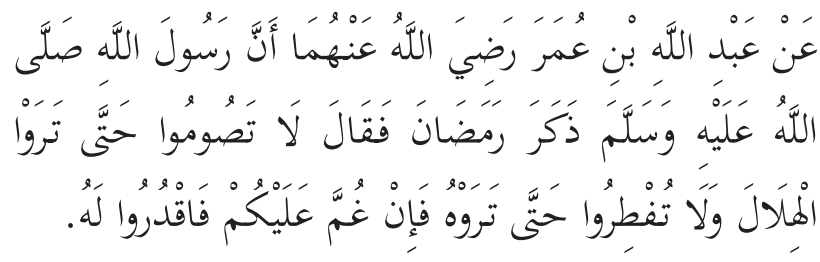

Maksudnya: "Jangan kamu berpuasa sehingga kamu melihat anak bulan dan jangan kamu berbuka sehingga kamu melihat anak bulan. Sekiranya mendung, maka taqdirkanlah ia." ${ }^{11}$

Daripada hadis-hadis di atas, Yūsuf al-Qaraḍāwī telah membuat kesimpulan terdapat tiga kaedah penentuan awal bulan qamari iaitu, (i) kaedah rukyah iaitu kaedah cerapan terhadap anak bulan, (ii) kaedah istikmal iaitu apabila anak bulan tidak kelihatan maka disempurnakan bulan qamari tersebut kepada 30 hari, dan, (iii) kaedah hisab iaitu melakukan pengiraan astronomi. ${ }^{32}$ Beliau mengemukakan hujah-hujahnya bagi menyokong penggunaan kaedah ketiga sekurang-kurangnya sebagai kaedah penafi. Akan tetapi, hadis ini tidak memfokuskan kepada kaedah yang digunakan. Oleh itu, ketetapan hukum yang perlu dilakukan adalah sama ada anak bulan kelihatan atau tidak.

Lantaran itu, apabila kembali pada isu kenampakan anak bulan pada zaman Rasulullah SAW, wasilah yang bersesuaian pada ketika itu adalah rukyah menggunakan mata kasar. Walau bagaimana pun, wasilah ini sentiasa berubah menghikut peredaran masa dan zaman. Tujuan bagi sesuatu pelaksanaan pula tidak berubah dan

30 Al-Bukhārī, Șah̄ịh al-Bukhārī, Kitāb al-Șaum, dalam Bab Qawl alNabī SAW, "Là Naktub wa Lā Naḥsub”, hadis no. 1908 (Riyāḍ: Dār al-Salam, 2000), 26-27.

31 Ibid, hadis no. 1906.

32 Al-Qaraḍ̄̄̄ī, Fiqh al-Șiyām, 23. 
sentiasa kekal sama. Sekiranya terdapat wasilah yang lebih baik serta mengaplikasikan wasilah tersebut. ${ }^{33}$

Kemudian beliau menyetujui pandangan Aḥmad Syākir di dalam kitabnya Awā'il Syuhūr al-'Arabiyyah bahawa 'illah disyariatkan rukyah anak bulan adalah disebabkan umat Islam pada ketika itu buta huruf. Akan tetapi, kini 'illah rukyah telah digantikan dengan kaedah hisab. Ini disebabkan oleh zaman ini, kemajuan ilmu sains dan teknologi telah berkembang pesat menyebabkan berlaku peralihan terhadap wasilah yang digunakan. Dengan perubahan wasilah ini, kaedah hisab dapat memberikan rukhșah atau kemudahan kepada para pencerap untuk melakukan aktiviti rukyah dengan baik terutamanya apabila dilakukan ketika cuaca yang mendung. ${ }^{34}$

Penjelasan ini bertepatan seperti mana kaedah usul fiqh:

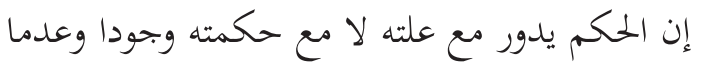

Maksudnya: Hukum ditentukan berdasarkan kepada kewujudan dan ketiadaan illah dan bukan hikmahnya. ${ }^{35}$

Berikutan itu, apabila hisab yang digunakan diperkuatkan lagi dengan penggunaan instrumen teleskop maka secara tidak langsung hasil cerapan yang diperolehi bebas daripada unsur penipuan. Ini kerana teleskop mengfokuskan kepada objek yang ingin dilihat dan dapat membantu mata kasar membezakan anak bulan dengan rekahan awan.

Menurut 'Abd al-Karīm Zaydān, kewajipan pelaksanaan ibadah puasa adalah berdasarkan kepada kenampakan anak bulan. Syarat wajib berpuasa ini kemudianya diperkuatkan lagi dengan melihat anak bulan menggunakan penglihatan mata. Akan tetapi, ianya bukanlah suatu larangan untuk melihat anak bulan dengan

33 Yūsuf al-Qaraḍāwī, Kayf Nata 'āmal ma 'a al-Sunnah (Qāhirah: Dār al-Syurūq, 2005), 145.

34 Aḥmad Muḥammad Syākir, Awā'il al-Syuhūr al-'Arabiyyah: Hal Yajūz Syar'an Ithbātuhā bi al-Hisāb al-Falak̄̄ Bahth Jadīd 'Ilm Hurr (Qāhirah: Dār al-Istiqāmah,1992), 7-8.

35 Abdul Azib Hussayn, Manhaj Ilmu Figh \& Usul Fiqh (Kuala Lumpur: Telaga Biru Sdn Bhd, 2012), 143. 
menggunakan bantuan instrumen optik seperti teleskop dan kamera. ${ }^{36}$ Lantaran itu, beliau menambah lagi suatu tuntutan syarak menjadi batas kepada sesuatu sekiranya ada suatu penyelesaian yang sudah pasti.

Manakala al-Muțī's pula menyatakan pengaplikasian penggunaan instrumen teleskop sebagai perantara bantuan bagi mata pencerap boleh diterima dari sudut syariah. Penggunaan ini masih mengekalkan prinsip rukyah tanpa mengetepikan penggunaan mata kasar. Tambahan lagi, teleskop mempunyai potensi yang tinggi dalam membantu mata kasar mengfokuskan hanya untuk melihat anak bulan bukan objek lain. Perbuatan ini dikenali sebagai 'ayn al-hilāl. ${ }^{37}$

Sementara itu, 'Abd al-Ḥāmid al-Syarwān̄̄în ${ }^{38}$ pula memberikan pandangan secara lebih eksplisit dengan mengemukakan kelebihan penggunaan istrumen ketika rukyah anak bulan. Penggunaan instrumen ini diharuskan kerana penggunaan ini tetap mengekalkan pengaplikasian rukyah. Apabila pencerap melihat anak bulan menggunakan teleskop, perbuatan ini tidak lari daripada menggunakan mata ketika melihat menggunakan teleskop.

'Abd al-Raḥman al-Jazīrī dan Abū Muḥammad Maḥmūd bin Ahmad al-'Ayn $\overline{1}^{39}$ pula mengetengahkan pandangan yang berbeza. Dalam permasalahan penentuan pensabitan anak bulan, tidak disyaratkan rukyah dengan syarat tertentu. Akan tetapi, penetapan masuknya awal bulan Hijri hanya didasarkan atas 2 perkara. Pertama, rukyah anak bulan dilakukan secara terus sekiranya berlatar belakang langit yang jelas. Manakala yang kedua pula ialah istikmal iaitu menyempurnakan jumlah hari dalam sebulan menjadi 30 hari jika keadaan langit menghalang mata daripada melihat anak bulan. Hakikatnya, permasalahan puasa bergantung kepada hasil rukyah. Akan tetapi ianya tidak menyebut keharusan

\footnotetext{
36 Ibid, 43-46.

37 Al-Muțī'ī, Mīzān al-I'tidāl (Bayrūt: Dār al-Kutub al-'Ilmiyyah, 2005), 35

38 'Abd al-Hāmid al-Syarwān̄̄, Hāsyiyah al-Syarwān̄ì (Bayrūt: Dār alKutub al-'Ilmiyyah, t. t ), $3: 332$.

39 Abū Muḥammad Maḥmud bin Aḥmad al-'Aynī, al-Bayānah fì Syarh al-Hidāyah (Bayrūt: Dār al-Fikr, 1980), 227.
} 
rukyah sama ada hanya menggunakan mata kasar sahaja atau turut menggunakan instrumen optik seperti teleskop.

Akan tetapi berbeza dengan Ibn Hajar. Menurut beliau perlaksanaan pensabitan anak bulan tidak boleh dilaksanakan menggunakan kaedah ru'yah bi al-fi'ti. Beliau menegaskan bahawa kaedah ini tidak diterima pakai disebabkan instrumen yang digunakan terdiri daripada alat yang diperbuat daripada kaca seperti kanta (nahw miratin). Tambahan lagi, beliau menguatkan penegasannya bahawa tidak menerima penggunaan instrumen seperti teleskop dengan padanan tidak menerima prinsip fizik terhadap pantulan cahaya melalui permukaan kaca atau air. Ini disebabkan oleh prinsip ini diragui apabila menggunakan kaca. ${ }^{40}$

Sementara itu, berdasarkan daripada hasil cerapan anak bulan Sya'ban $1431 \mathrm{H}$ mendapati bahawa elognasi anak bulan adalah $8.5^{\circ}$, altitud pula $1^{\circ} 41^{\prime} 48^{\prime \prime}$ dan umur bulan 16.09 jam. Penyaksian anak bulan ini diterima kerana telah memenuhi kriteria Imkān al$R u ' y a h$. Walaupun altitud bulan berada pada kurang daripada $2^{\circ}$, akan tetapi anak bulan tersebut berada pada kedudukan elognasi yang besar iaitu $8.5^{\circ}$ dan umur bulan telah melepasi had minimum 8 jam. Oleh itu, ianya boleh dianggap sebagai anak bulan. Sekiranya situasi ini berlaku pada pensabitan anak bulan Ramadan, maka keesokkannya ibadah puasa wajib dilaksanakan. Ini kerana anak bulan yang dilihat adalah sah memenuhi syarak dan kriteria Imkān al-Ru'yah.

\section{KESIMPULAN}

Oleh yang demikian, dua kesimpulan dapat dibuat berdasarkan pandangan di atas. Pertama, penggunaan teleskop diharuskan kerana pengunaan ini dapat membantu kesaksian anak bulan. Penetapan penggunaan ini masih menggunakan kaedah asal iaitu menggunakan mata kasar tetapi dibantu dengan menggunakan teleskop. Kedua, kenampakan anak bulan ini perlu memenuhi kriteria Imkān al-Ru'yah. Sekiranya memenuhi kriteria ini, anak

\footnotetext{
40 BJ Habibie, Rukyah dan Teknologi: Upaya Mencari Kesamaan Pandangan Tentang Penentuan Ramadhan dan Syawal (Jakarta: Gema Insani Press, 1991), 69-75.
} 
bulan yang dilihat menerusi teleskop boleh dianggap sebagai anak bulan.

Walaupun nas syarak telah menetapkan bahawa metod yang perlu dilaksanakan bagi pensabitan anak bulan adalah rukyah menggunakan mata kasar. Namun demikian, metod ini berkemungkinan berlakunya kesilapan dalam penyaksian yang dilakukan. Oleh hal yang demikian, dengan adanya instrumen astronomi iaitu teleskop ianya dapat membantu kesaksian anak bulan.

Berdasarkan analisis yang telah dibuat, penggunaan teleskop sebagai alat bantuan bagi melihat anak bulan didapati mampu mencapai serta memenuhi objektif untuk menentukan kenampakan anak bulan yang lebih baik. Berbanding jika hanya bergantung dengan pengamalan rukyah menggunakan mata kasar sematamata.

Lantaran itu, penulis mengemukakan bahawa kaedah penggunaan teleskop dan kamera DSLR perlu dipertimbangkan dengan syarat tertentu. Sekiranya anak bulan berada pada ketinggian $0^{\circ}$ hingga $2^{\circ}$ di atas ufuk, keadaan saiz anak bulan adalah terlalu kecil. Tambahan lagi, apabila berada pada keadaan altitud rendah, anak bulan berada pada kedudukan yang terlalu hampir dengan matahari menyebabkan kecerahan matahari dan latar belakang langit yang masih tinggi melitupi kecerahan anak bulan yang sangat minimum. Oleh itu, anak bulan tidak mungkin dapat dilihat menggunakan mata kasar. Sekiranya kesaksian menggunakan mata kasar, ditakuti berlaku penipuan apabila terdapat pencerap yang menganggap rekahan cahaya awan sebagai anak bulan.

Dalam situasi ini, kenampakan anak bulan menggunakan teleskop dan kamera DSLR tanpa kesaksian menggunakan mata kasar adalah diterima dan boleh dianggap sebagai anak bulan. Ini kerana, apabila dilihat kembali kepada pendefinisian anak bulan, ianya tidak terkeluar daripada ruang lingkup anak bulan sebagai goresan garis cahaya yang nipis. Apabila menggunakan teleskop dengan disertai kamera DSLR kelihatan sebagai garis cahaya nipis di tepi bulatan bulan yang mengarah ke matahari dan ianya perlu memenuhi kriteria Imkān al-Ru'yah dalam konteks Malaysia. 


\section{BIBLIOGRFI}

Abdul Azib Hussain. Manhaj Ilmu Fiqh \& Usul Fiqh. Kuala Lumpur: Telaga Biru Sdn Bhd, 2012.

'Abd al-Amīr Mu'min. Qāmūs Dār 'Ilm al-Falakī. Bayrūt: Dār al-'Ilm li al-Malāyīn, 2006.

Aḥmad Muḥammad Syākir. Awā'il al-Syuhūr al-'Arabiyyah: Hal Yajūz Shar' 'an Ithbātuhā bi al-Hisāb al-Falakī Bahth Jadīd 'Ilm Hurr. Qahirah: Dār al-Istiqāmah,1992.

Al-'Ayn̄̄, Abū Muḥammad Maḥmūd bin Aḥmad. Al-Bayānah fì Syarh al-Hidāyah. Bayrūt: Dār al-Fikr, 1980.

Al-Aẓharī, Muḥammad Aḥmad Abū Manșūr. Tahdhīb al-Lughah. Bayrūt: Dār Ihyāà al-Turāth al-‘Arabī, 2001.

Al-Bukhārī, Muḥammad Ibn Ismā'il Abī 'Abd Allah. Șahīh alBukhārī. Riyāḍ: Dār al-Salam, 2000.

Al-Muṭī'ì. Mīzān al-I'tidāl. Bayrūt: Dār al-Kutub al-'Ilmiyyah, 2005.

Al-Syarwān̄̄, 'Abd al-Ḥāmid. Hasyiyah al-Syarwān̄̄. Bayrūt: Dār al-Kutub al-'Ilmiyyah, t.t.

Abū al-Ḥasan 'Alī bin Aḥmad. Al-Wājìz fì Tâfsìr al-Kitāb al'Azīz. Damsyiq: Dār al-Qalam, 1995.

Fayrūz Ābādī, Majd al-Dīn Muḥammad Ibn Ya'qūb. Qāmūs alMuḥịt. Māktāb Taḥqīq fĩ Mūassāsah al-Risālah, 1998.

Bahagian Hal Ehwal Islam, Pelaksanaan Rukyah dan Hisab di Malaysia. (Koleksi Kertas Kerja Seminar Persatuan Falak Syar'i Malaysia, Kuala Lumpur:Persatuan Falak Syari’i Malaysia,1993): 175.

BJ Habibie. Rukyah dan Teknologi: Upaya Mencari Kesamaan Pandangan Tentang Penentuan Ramadhan dan Syawal. Jakarta: Gema Insani Press,1991.

Fatoohi, Louay J., Stephenson et al. "The Babylonian First Visibility of the Lunar Crescent: Data and Criterion". 
Journal for the History of Astronomy 30 (1999): 51-72.

Fotheringham, John Knight."On the Smallest Visible Phase of the Moon". Monthly Notices of the Royal Astronomical Society 70 (1910): 527-531.

Haron Din, "Melihat Anak Bulan di Malaysia: Masalah dan Kemungkinan". (Kertas Kerja Seminar dibentangkan di Universiti Kebangsaan Malaysia, 22-24 Januari 1982).

Ibrāhīm Anīs, 'Abd al-Ḥalīm Muntașir, 'Ațiyyah al-Sawāliḥ̄i, et al. Al-Mu'jam al-Wasìt. Istanbul: t. t.

Ibn Manzūr. Lisān al- 'Arab. Bayrūt: Dār Iḥyā’ al-Turāth al- Arabī, t. th.

Jabatan Kemajuan Islam Malaysia (JAKIM). http://www.islam. gov.my/e-falak/tempat-cerapan. Diakses pada 20 Mac 2014.

Jabatan Fizik Angkasa. Laporan Kajian Cerapan Kenampakan Hilal Tahun 1421-1431 Hijrah. Kuala Lumpur: Makmal Fizik Angkasa.

Joko Satria A, Chin Wei Loon, Nazhatulshima Ahmad et al. "Pensabitan Hilal Menerusi Teknik Pengimejan". Dalam Dimensi Penyelidikan Astronomi Islam, (ed.) Saadan Man et al. (Kuala Lumpur: Jabatan Fiqh dan Usul, Akademi Pengajian Islam, Universiti Malaya, 2013), 95.

Joko Satria, Chin Wei Loon, Nazhatulshima Ahmad, et al. "Pensabitan Anak bulan Menerusi Teknik Pengimejan," Kertas Kerja Jabatan Kemajuan Islam Malaysia (Kuala Lumpur: Makmal Fizik Angkasa, Universiti Malaya, 2011), $5-8$.

Khadijah Ismail,"The Philosophical and Empirical Investigation on Moon Width and Brightness and Its Relationship with Crescent Visibility and Prediction Criteria in Islamic Calendar," (Disertasi Sarjana, Universiti Malaya, 2010) Kordi, Ayman S., "The Psychological Effect on Sightings of the New Moon", The Observatory 123 (2003): 219-222. 
Mc Nally, D. "The Length of the Lunar Crescent", Quarterly Journal of the Royal Astronomical Society 24 (1983): 417429.

Meade Instruments. http://www.meade.com/1x200. Diakses pada 20 Mac 2014.

Mikhail, J.S., Asaad, A.S., Nawar, S. et al. "Improving the Crescent Visibility Limits Due to Factors Causing Decrease in the Sky Twilight Brightness." Earth, Moon and Planets, 70 (1995): 109-121.

Mohd Zambri Zainuddin, Mohd Saiful Anwar Nawawi, Nazhatul Shima. "Sky Illumination for Lunar Crescent Visibility at Telok Kemang, Malaysia." (Proceedings of the Second Emirates Astronomical Conference at Abu Dhabi, United Arab Emirates, 30 May- 1 June 2010).

Samad Abu et al. Kaedah Penentuan Awal Hijrah. Putrajaya: Jabatan Kemajuan Islam Malaysia, 2001.

Schaefer, Bradley E., "Visibility of the Lunar Crescent", Quarterly Journal of the Royal Astronomical Society 29 (1988): 511.

Sultan, Abdul Haq. "First Visibility of the Lunar Crescent: Beyond Danjon's Limit", The Observatory 127 (2007): 53-59.

The Malaysia Standard Time (SIRIM). http://time.sirim.my/. Diakses pada 20 Mac 2014.

Al-Qaraḍāwī, Yūsuf. Fiqh al-Șiyām. Qāhirah: Maktabah alWahbah, 2006.

Al-Qaraḍāwī, Yūsuf. Kayf Nata 'āmal ma 'a al-Sunnah. Qāhirah: Dār al-Syuruq, 2005. 